\title{
Antidialectics: Vodou and The Haitian Revolution in Opposition to The African American Civil Rights Movement
}

\author{
Paul C Mocombe* \\ West Virginia State University, USA
}

*Corresponding author: Paul C Mocombe, West Virginia State University, The Mocombeian Foundation Inc., USA

\begin{abstract}
This work, using a structurationist approach to consciousness constitution, focuses on how and why the purposive - rationality of the originating moments of the Haitian Revolution and Vodou diametrically opposes that of the African American Civil Rights movement and the desires of the Affranchis of Haiti. The author concludes that the antidialectical intent of the originating moments of the Haitian Revolution at Bwa Kayiman (Bois Caiman) was not for equality of opportunity, distribution, and recognition with whites by reproducing their norms and structure, as in the case of the African American civil rights movement under the purposiverationality of liberal bourgeois black Protestant men. Instead, it was a clarion call, which emerges out of Vilokan/Haitian Idealism, for the reconstitution of a new world order or structuring structure "enframed" by an African linguistic and spiritual community, Vodou and kreyol, respectively, grounded in, and "enframing," liberty and fraternity among blacks or death. In fact, the author posits that it is the infusion of the former worldview, liberal bourgeois Protestantism via the Protestant Ethic and the spirit of capitalism, on the island by the mulatto elites and petit-bourgeois free persons of color, Affranchis, looking to Canada, France, and America for equality of opportunity, distribution, and recognition that not only threatens Haiti and its practical consciousnesses, Vodou and Kreyol, contemporarily, but all life and civilizations on earth because of its economic growth and accumulative logic within the finite space and resources of the earth.
\end{abstract}

Keywords: African-Americanization; phenomenological structuralism; Vodou; Religiosity; Black Diaspora; Dialectical; Antidialectical; Haitian Epistemology; Vilokan/Haitian Idealism

\section{Introduction}

The dialectical integration of blackAmericans into the Protestant Ethic and the spirit of capitalism of the West via slavery, the African American civil rights movement, and globalization marks the end of black American history as a distinct African worldview manifesting itself onto the world. A black/African practical consciousness as represented in Haitian Vodou and Kreyol, for example, manifesting itself in praxis and the annals of history via the nation-state of Ayiti/ Haiti is slowly being supplanted by a universal Protestant Ethic and the spirit of capitalism phenotypically dressed in multiethnic, multiracial, and multisexual skins speaking for the world. This latter worldview has not only erased a distinct African practical consciousness among black Americans, but via the AfricanAmericanization of the black diaspora in globalization through the hip-hop culture of the black American underclass, on the one hand, and the prosperity gospel of the black American church and bourgeoisie on the other is seeking to do the same among blacks globally in the diaspora while simultaneously destroying all life on earth [1]. This work focuses on how and why the purposiverationality, antidialectics, of the originating moments of the Haitian Revolution and Vodou diametrically opposes that of the African American Civil Rights movement. The author concludes that the intent of the originating moments of the Haitian Revolution at Bwa Kayiman (Bois Caiman) was not for equality of opportunity, distribution, and recognition with whites by reproducing their norms and structure, as in the case of the African American civil rights movement under the purposive-rationality of liberal bourgeois black Protestant men, but for the reconstitution of a new world order or structuring structure (libertarian communism) "enframed" by an African linguistic and spiritual community, Vodou 
and kreyol, respectively, grounded in, and "enframing," liberty and fraternity among blacks or death. In fact, the author posits that it is the infusion of the former worldview, liberal bourgeois Protestantism via the Protestant Ethic and the spirit of capitalism, on the island by the mulatto elites and petit-bourgeois free persons of color, Affranchis, looking to Canada, France, and America for equality of opportunity, distribution, and recognition that not only threatens Haiti and its practical consciousnesses, Vodou and Kreyol, contemporarily, but all life and civilizations on earth because of its dialectical economic growth and accumulative logic within the finite space and resources of the earth.

\section{Background of the problem}

Traditional interpretations of the Haitian Revolution and the black American Civil Rights movement of the 1960s attempt to understand the two sociohistorical phenomena within the dialectical logic of Hegel's master/slave dialectic [2-4]. Concluding that both events represent a dialectical struggle by the enslaved Africans, who have internalized the rules of their masters, for equality of opportunity, recognition, and distribution within and using the metaphysical discourse of their former white masters to convict them of not identifying with their norms, rules, and values as recursively organized and reproduced by blacks. This traditional liberal bourgeois interpretation of the Haitian revolution attempts to understand its denouement through the sociopolitical effects of the French Revolution when the National Constituent Assembly (Assemblée Nationale Constituante) of France passed la Déclaration des droits de l'homme et du citoyen or the Declaration of the Rights of Man and Citizen in August of 1789. The understanding from this perspective is that the slaves, many of whom could not read or write French, understood the principles, philosophical and political principles of the Age of Enlightenment, set forth in the declaration and therefore yearned to be like their white masters, i.e., freemen seeking liberty, equality, and fraternity, the rallying cry of the French Revolution [4-16].

Although, historically this understanding holds true for the mulattoes and free petit-bourgeois blacks or Affranchis who used the language of the declaration to push forth their efforts to gain liberty, equality, fraternity with their white counterparts as slaveholders and masters as brilliantly highlighted by Laurent Du Bois [3]. This position, I posit here, is not an accurate representation for the Africans who met at Bois Caïman, the originating moments of the Haitian Revolution. The Affranchis, embodied in the person of Toussaint Louverture, for example, like their black American middle class counterparts, dialectically pushed for liberty, equality, and fraternity with their white counterparts at the expense of the Vodou discourse and Kreyol language of the pep, the majority of the enslaved Africans who were not only discriminated against by whites but by the mulattoes and free blacks as well who sought to reproduce the French language, culture, religion, and laws of their former slavemasters on the island [5]. Toussaint believed that the technical and governing skills of the Blancs (whites) and Affranchis would be sorely needed to rebuild the country, along the lines of white civilization, after the revolution and the end of white rule on the island. In fact, Toussaint was not seeking to make Haiti an independent country; but sought to have the island remain a French plantation colony, like Martinique and Guadeloupe, without slavery [3]. Although Dessalines's nationalistic position, which was similar to Toussaint's, would become dominant after the capture of Toussaint in 1802, his (Dessalines's) assassination by a plot between the mulatto, Alexandre Pétion, and Henri Christophe, would see to it that the Affranchis's purposive-rationality would come to historically represent the ideals of the Haitian quest for independence. This purposive-rationality of the Affranchis, to adopt the ontological and epistemological positions of whites by recursively organizing and reproducing their language and ways of being-in-the-world is, however, a Western liberal dialectical understanding of the events and their desire to be like their white counterparts, which stands against the anti-dialectical purposive rationality, which emerged out of the African/Haitian Epistemology, Vilokan/Haitian Idealism, of Boukman Dutty, Cecile Fatiman, the rest of the maroon Africans who congregated for the Petwo Vodou ceremony at Bois Caïman/ Bwa Kayiman. The difference between what the Africans at Bois Caïman wanted and the aspirations of the mulattoes or Affranchis can be summed up through a parallel or complimentary analysis of the dialectical master/slave relationship of the black American experience with their white masters in America [17-31].

Using a structurationist approach to practical consciousness constitution, what Paul C Mocombe [6] calls phenomenological structuralism, this work compares and contrasts the purposive rationality of the black American civil rights movement with that of the originating moments of the ceremony of Bois Caiman. In keeping with the tenets of phenomenological structuralism, the emphasis is on the ideals of structures that social actors internalize and recursively organize and reproduce as their praxis in the material world. In this case, the argument is that two distinct forms of system and social integration would characterize black American and Haitian life, which made their approaches to slavery and colonialism totally distinct: dialectical on the one hand; and antidialectical on the other [31-48].

\section{Theory and Method}

Beginning in the sixteenth century, Africans were introduced into the emerging global Protestant capitalist world social structure as slaves. Given their economic material conditions, their African practical consciousnesses, i.e., bodies, languages, ideologies, etc., were dialectically represented by European whites as primitive forms of being-in-the-world to that of the dominant white Protestant bourgeois social order with the ever-declining significance of Catholicism following the Protestant Reformation [7]. From this sociohistorical perspective, under the "contradictory 
principles of marginality and integration" [7] the majority of African consciousness in America especially was reshaped as a "racial classin-itself" (blacks), a "caste in class," forced to embody the structural terms (bourgeois ideals in the guise of the protestant ethic) of the dominant global (capitalist) social relations of production, over all other "alternative" African adaptive responses to its then organizational form, slavery [48-64].

This embodiment or internalization of bourgeois ideals, in the guise of the Protestant Ethic, by the majority of Africans in America amidst their poor material conditions created by the social relations of Protestant capitalist organization, in keeping with traditional readings of the black American struggle for freedom, eventually made the struggle to obtain equality of opportunity, distribution, and recognition with their white Protestant bourgeois counterparts amidst racial and class discrimination their goal. This goal, brilliantly captured by W.E.B. Du Bois in his work The Souls of Black Folk, progressively crept into their African based spiritualism, which dialectically subsequently became synthesized with the Protestant Ethic of the global capitalist Protestant social structure leading to the ever-increasing materialization of black American faiths and practical consciousness along the lines of their former white slave masters. Hence, the subsequent aim of the majority of black Americans, as embodied in the black American civil rights movement, became a movement for equality of opportunity, distribution, and recognition led by liberal black Protestant bourgeois male preachers (hybrid simulacrum of their white colonizers) like Martin Luther King Jr. against alternative responses to enslavement by convicting the society of not identifying with their norms and values, which black Americans embodied and recursively organized and reproduced in their practices [8].

Conversely, the Haitian Revolution as initiated on August $14^{\text {th }}$, 1791 at Bois Caïman by Boukman Dutty and Mambo Cecile Fatiman was led by various representatives of African nations seeking to recursively reorganize and reproduce their African practicalconsciousness/thesis, the Vodou Ethic and the spirit of communism, which emerges out of their African ontology and epistemology, Vilokan/Haitian Idealism, in the world against the bourgeois liberalism of whites and the mulatto or Affranchis class of Haiti, who would subsequently, with the assassination of the houngan, Vodou priest, Jean-Jacques Dessalines in 1806, undermine that attempt for a more liberal purposive-rationale, similar to that of the black American civil-rights movement, that would reintroduce wage-slavery and peonage on the island [64-70].

Haitians celebrate Bois Caïman as the beginning of the Haitian Revolution in August of 1791. At Bois Caïman/Bwa Kay Iman (near Boukman's house), the Jamaican-born houngan, Vodou priest, Boukman Dutty, initiated the Haitian Revolution on August 14, 1791 when he presided over a Petwo Vodou ceremony in Kreyol in the area, which is located in the mountainous Northern corridors of the island. Accompanied by a woman, the mambo Vodou priestess
Cecile Fatiman, taken by the spirits of the lwa/loas, Ezili Danto/ Erzulie Danthor, they cut the throat of a black pig and had all the participants in attendance drink the blood. According to Haitian traditions, Boukman and the participants, via Boukman's prayer, swore two things to the lwa Ezili Danto, the Goddess of the Haitian nation, present in Fatiman if she would grant them success in their quest for liberty against the French. First, they would never allow for inequality on the island; second, they would serve bondye/Gran-Met (their good god) and its 401 manifestations, lwaes of Vodou and not the white man's god "which inspires him with crime:"

Bon Dje ki fè la tè. Ki fè soley ki klere nou enro. Bon Dje ki soulve lanmè. Ki fè gronde loray. Bon Dje nou ki gen zorey pou tande. Ou ki kache nan niaj. Kap gade nou kote ou ye la. Ou we tout sa blan fè nou sibi. Dje blan yo mande krim. Bon Dje ki nan nou an vle byen fè. Bon Dje nou an ki si bon, ki si jis, li ordone vanjans. Se li kap kondui branou pou nou ranpote la viktwa. Se li kap ba nou asistans. Nou tout fet pou nou jete potre dje Blan yo ki swaf dlo lan zye. Koute vwa la libète $k$ ap chante lan kè nou.

The god who created the sun which gives us light, who rouses the waves and rules the storm, though hidden in the clouds, he watches us. He sees all that the white man does. The god of the white man inspires him with crime, but our god calls upon us to do good works. Our god who is good to us orders us to revenge our wrongs. He will direct our arms and aid us. Throw away the symbol of the god of the whites who has so often caused us to weep, and listen to the voice of liberty, which speaks in the hearts of us all [71-75].

That night the slaves revolted first at Gallifet Plantation, then across the Northern Plains. Toussaint Louverture and Jean-Jacques Dessalines would join the rebellion after Boukman was captured and beheaded by the French. And as the proverbial saying goes, the rest is history. Under Jean-Jacques Dessalines, who crowned himself emperor for life, Haiti became the first free black nation-state in the world in 1804, the only successful slave rebellion in recorded history, the first democratic nation, and the second republic after the United States of America in the Western Hemisphere [75-79].

The centering of Vodou and Kreyol are the divergent paths against slavery and liberal bourgeois Protestantism that sets the originating moments of the Haitian Revolution apart, as a distinct phenomenon, from the desires and purposive-rationale of an elite liberal hybrid group, the mulatto elite and black petit-bourgeois class or Affranchis in Haiti and liberal black Protestant bourgeois male preachers of America, seeking to serve as the bearers of ideological and linguistic domination for the black masses in both countries by recursively (re) organizing and reproducing the agential moments of their former colonizers within the logical constraints of Hegel's master/slave dialectic. To only highlight the latter, liberal bourgeois Protestant initiative, over the former, originating moments of the Haitian revolution, under the purview 
of a Hegelian master/slave universal dialectic, as so many theorists, including the work, Black Jacobins, of CLR James, and Susan BuckMorss's [4], Hegel, Haiti, and Universal History, is to deny the existence of the African practical-consciousness, Haitian Idealism as expressed through the Vodou Ethic and the spirit of communism, that has been seeking to institute its practical consciousness in the world since the beginning of the slave trade in favor of the liberal bourgeois Protestantism of whites and the mulatto and black petitbourgeois elites who have yet to be able to stamp out, as was done to the black American, the African linguistic system, Kreyol, and practical-consciousness, Vodou, of the Haitian masses, by which Haiti's provinces have been constituted [79-90].

\section{Discussion}

As in the case of CLR James's work, Black Jacobins, Susan Buck Morss [4] in her work, Hegel, Haiti, and Universal History attempts to understand the originating moments of the Haitian Revolution metaphorically through Hegel's master/slave dialectic. Suggesting, in fact, that it is the case of Haiti that Hegel utilized to constitute the metaphor:

Given the facility with which this dialectic of lordship and bondage lends itself to such a reading, one wonders why the topic Hegel and Haiti has for so long been ignored. Not only have Hegel scholars failed to answer this question; they have failed, for the past two hundred years, even to ask it (2009, p. 56).

My position here is that James's and Morss's conclusions do not hold true for the Africans who met at Bois Caïman, and only holds true for the case of the Affranchis of Haiti-who usurped, following their assassination of Dessalines, the originating moments of the Revolution from the Africans who met at Bois Caïman-and the black Americans who, in choosing to rebel against their former masters, were not risking death to avoid subjugation, but in rebelling were choosing life in order to be like the master and subjugate.

In Hegel's master/slave dialectic as Morss explains,

Hegel understands the position of the master in both political and economic terms. In the System der Sittlichkeit (1803): "The master is in possession of an overabundance of physical necessities generally, and the other [the slave] in the lack thereof." At first consideration the master's situation is "independent, and its essential nature is to be for itself"; whereas "the other," the slave's position, "is dependent, and its essence is life or existence for another." The slave is characterized by the lack of recognition he receives. He is viewed as "a thing"; "thinghood" is the essence of slave consciousness-as it was the essence of his legal status under the Code Noir. But as the dialectic develops, the apparent dominance of the master reverses itself with his awareness that he is in fact totally dependent on the slave. One has only to collectivize the figure of the master in order to see the descriptive pertinence of Hegel's analysis: the slaveholding class is indeed totally dependent on the institution of slavery for the "overabundance" that constitutes its wealth. This class is thus incapable of being the agent of historical progress without annihilating its own existence. But then the slaves (again, collectivizing the figure) achieve selfconsciousness by demonstrating that they are not things, not objects, but subjects who transform material nature. Hegel's text becomes obscure and falls silent at this point of realization. But given the historical events that provided the context for The Phenomenology of Mind, the inference is clear. Those who once acquiesced to slavery demonstrate their humanity when they are willing to risk death rather than remain subjugated. The law (the Code Noir!) that acknowledges them merely as "a thing" can no longer be considered binding, although before, according to Hegel, it was the slave himself who was responsible for his lack of freedom by initially choosing life over liberty, mere self-preservation. In The Phenomenology of mind, Hegel insists that freedom cannot be granted to slaves from above. The self-liberation of the slave is required through a "trial by death": "And it is solely by risking life that freedom is obtained...The individual, who has not staked his life, may, no doubt, be recognized as a Person [the agenda of the abolitionists!]; but he has not attained the truth of his recognition as an independent self-consciousness." The goal of this liberation, out of slavery, cannot be subjugation of the master in turn, which would be merely to repeat the master's "existential impasse," but, rather, elimination of the institution of slavery altogether (53-56)

The Africans at Bois Caïman, given that they were already recursively reproducing their African practical consciousness in the maroon community of Bois Caïman away from the master/slave dialectic of whites neither cared for the master, nor his structuring metaphysics, but instead wanted to be free to exercise their African practical consciousness, which would be precarious, given the possibility of their re-enslavement if captured, by whites and the Affranchis, who also practiced slavery, remained on the island. In essence, the events at Bois Caïman represented an attempt by the Africans to exercise their already determining independent African self-consciousness against the whites and Affranchis's dependent self-consciousness which sought to repeat the masters' "existential impasse." The liberal Affranchis and the black Americans, in other words, who would lead the civil rights movement, wanted, given that their very practical consciousness was determined by their relations to, and yearning to be like, their masters, rebelled in order to themselves be "free" masters and not an "independent self-consciousness." In essence, the Affranchis, like their black American counterparts, merely rebelled in order to be like their masters, and sought neither to subjugate the master nor eliminate "the institution of slavery altogether," since their consciousness as slaves was from the onset revealed to them only through the eyes of the master. Hence, the only other consciousness they had, outside of their slave consciousness, "thinghood," was that of the master, whose position they desired, and that of the African masses whose practical consciousness they abhorred. But Boukman, Fatiman, and the other maroon Africans of Bois Caïman had their abhorred 
African Consciousness, which to revert to. The Affranchis, like their black American counterparts did not. Be that as it may, whereas the former sought to institute a new historical/universal, Absolute, order onto the material resource framework of Haiti by invoking the aid of their lwaes/loas to assist them in rooting out the whites and their gods, the latter, like their black American counterparts, wanted to maintain the status quo, the master/slave relationship by which their practical consciousness was constituted, in a national position of their own [91-116].

In other words, black Americans subjectified/objectified in the "Protestant Ethic and the spirit of capitalism" of American society were completely subjectified and subjugated on account of race and class position $[8,9]$. They were subjectified objects, i.e., slaves, things, whose initial practical consciousness prior to their enslavement was used dialectically by the master, by presenting the practical consciousness of the slave as backwards and damned within the metaphysics of the master's practical consciousness, against the slave to objectify them as a thing. W.E.B Du Bois, for example, relying on the racial and national ideology of the late nineteenth and early twentieth century theoretically, en framed by Hegel's master/slave dialectic, conceived of the ambivalence that arose in him as a self-conscious thing, as a result of the "class racism" (Étienne Balibar's term) of American society, as a double consciousness: "two souls," "two thoughts," in the Negro whose aim is to merge these two thoughts into one distinct way of being, i.e., to be whole again [117-125].

After the Egyptian and Indian, the Greek and Roman, the Teuton and Mongolian, the Negro is a sort of seventh son, born with a veil, and gifted with second-sight in this American world, -a world which yields him no true self-consciousness, but only lets him see himself through the revelation of the other world. It is a peculiar sensation, this double consciousness, this sense of always looking at one's self through the eyes of others, of measuring one's soul by the tape of a world that looks on in amused contempt and pity. One ever feels his twoness, -an American, a Negro; two souls, two thoughts, two unreconciled strivings; two warring ideals in one dark body, whose dogged strength alone keeps it from being torn asunder.

The history of the American Negro is the history of this strife, -this longing to attain self-conscious manhood, to merge his double self into a better and truer self. In this merging he wishes neither of the older selves to be lost. He would not Africanize America, for America has too much to teach the world and Africa. He would not bleach his Negro soul in a flood of white Americanism, for he knows that Negro blood has a message for the world. He simply wishes to make it possible for a man to be both a Negro and an American, without being cursed and spit upon by his fellows, without having the doors of Opportunity closed roughly in his face. This, then, is the end of his striving: to be a coworker in the kingdom of culture, to escape both death and isolation, to husband and use his best powers and his latent genius [3].
This double-consciousness resulting from his thingness in relation to the master's consciousness, $\mathrm{Du}$ Bois alludes to, in this famous passage of his work The Souls of Black Folk, is not a metaphor for the racial duality of black American life in America $[8,9]$. Instead, it speaks to Du Bois's, as a black liberal bourgeois Protestant man, ambivalence about the society because it prevents him from exercising, not his initial African practical consciousness which is "looked on in amused contempt and pity," but his true (master) American consciousness because of the society's antiliberal and discriminatory practices, which made him a thing, i.e., slave. Although over time his "thinghood" forced Du Bois to adopt "pan-African communism" against his early beliefs in liberal bourgeois Protestantism, i.e., his desire to be like the masters, whites. Du Bois, in this passage, like the many black Americans who would share his class position and liberal bourgeois Protestant worldview, does not want an independent self-consciousness that is not the masters since the only other consciousness he is familiar with is that of the slaves, but simply wants to be like the collective dependent masters, whites, "without being cursed and spit upon by his fellows, without having the doors of Opportunity closed roughly in his face." His later pan-African communist message simply turns this desire, the attempt to be a master, into a desire to constitute the master/slave dialectic in a national position of his own. But contrary to this later "pan-African communist" message against assimilation for a nationalist position of his own, however, to make themselves whole the majority of black Americans of the civil rights movement, especially, did not yearn for or establish (by averting their gaze away from the eye of power or their white masters) a new independent object formation or totality, based on the initial "message" of their people prior to their encounter with the master, which spoke against racial and class stratification and would have produced heterogeneity into the American capitalist bourgeois world-system; instead, since there was no other "message" but that of the society which turned and represented the "original" African message of their people into inarticulate, animalistic backward gibberish, they (blacks) turned their gaze back upon the eye of power (through protest and success in their endeavors) for recognition as "speaking subjects" of the society seeking not to subjugate the master in a national position of their own but for equality of opportunity, distribution, and recognition with their white counterparts. Power hesitantly responded by allowing some of them (the hybrid modern "other" liberal bourgeois Protestant) to partake in the order of things, which gave rise to the black American identity, the liberal black bourgeoisie or hybrids, which delimits the desired agential moments of the social structure for all blacks [8-13].

Thus black American protest as a structurally differentiated "class-in-itself" (subjectified/objectified thing) led by this liberal black bourgeoisie within the American protestant bourgeois master/slave order did not reconstitute American society, but integrated the black subjects, whose ideals and practices (acquired 
in ideological apparatuses, i.e., schools, law, churches (black and white)), as speaking subjects, were that of the larger society, i.e., the protestant ethic, into its exploitative and oppressive order-an order which promotes a debilitating performance principle actualized through calculating rationality, which may result in economic gain for its own sake for a few predestined individuals. The black American, like the early Du Bois of the Souls prior to his conversion to pan-African communism, in a word, became like their masters within the master/slave dialectic, which constituted their historical experiences.

The same can be said for the Affranchis of Haiti, who sought for equality of opportunity, distribution, and recognition with their blanc counterparts at the expense of the agential initiatives of the Bois Caïman African participants. The Affranchis, like Toussaint, for example, who owned African slaves, rebelled not to eliminate slavery or subjugate the master, but to be a master, like their liberal black American counterparts, through their dialectical claim for equality of opportunity, distribution, and recognition. Their slave status only revealed to them the "other" consciousness in the dialectic, i.e., the master consciousness. Therefore, their desire was not to be slaves, who had no other consciousness to look to but that of the newly arrived Africans and the maroon Africans, but masters who enslaved the other slaves, i.e., the newly arrived Africans and the marooned Africans, who were not like themselves. This desire of Toussaint, for example, to be like the master, however, was not the aim of Jean-Jacques Dessalines, Boukman, Cecile Fatiman, and the other participants at Bois Caïman. The former, Affranchis, like their black American counterpart, wanted equality of opportunity and recognition from, and with, their former white masters by recursively organizing and reproducing their (the slave masters) liberal agential moments; the latter, Boukman, Fatiman, Jean-Jacques Dessalines, and the Africans of Bois Caïman did not, but instead sought to anti-dialectically reify and practice their traditional African ways of life against the purposive-rationality of their former white masters. The slaves at Bois Caïman were already an independent self-consciousness in their maroon communities. They did not share in the "existential impasse" of their masters. The originating Vodou and Kreyol moments of the Revolution was an attempt to get rid of the whites and Affranchis, who desired to be whites, in order that they may recursively organize and reproduce their practical consciousness, not to be like their white masters as Toussaint and the rest of the Affranchis desired. That the Affranchis would come to direct the Revolution after the death of Dessalines October, 17th, 1806, would give rise to their purposive-rationality, their desire for equality of opportunity, distribution, and recognition within the global capitalist social structure, at the expense of the agential moments of Boukman, Fatiman, and the other participants of Bois Caïman who sought to anti-dialectically manifest their selfconsciousness onto the stage of history by evoking the aid of their own Gods to fight against the Gods and metaphysics of the whites and Affranchis who had adopted the purposive-rationality of their white masters [126-133].

\section{Conclusion}

Essentially, the Frankfurt school's "Negative Dialectics" represents the means by which the Du Bois of The Souls, the majority of liberal bourgeois black Americans, and the Affranchis of Haiti confronted their historical situation. The difference between the "negative dialectics" of Du Bois of The Souls, the majority of liberal bourgeois black Americans, the Affranchis, and the discourse or purposive rationality of the enslaved Africans of Bois Caïman is subtle, but the consequences are enormously obvious. For the Frankfurt school, "[t]o proceed dialectically means to think in contradictions, for the sake of the contradiction once experienced in the thing, and against that contradiction. A contradiction in reality, it is a contradiction against reality" (Adorno, 1973 [1966]: 145). This is the ongoing dialectic they call "Negative Dialectics:"

Totality is to be opposed by convicting it of nonidentity with itself-of the nonidentity it denies, according to its own concept. Negative dialectics is thus tied to the supreme categories of identitarian philosophy as its point of departure. Thus, too, it remains false according to identitarian logic: it remains the thing against which it is conceived. It must correct itself in its critical course-a course affecting concepts which in negative dialectics are formally treated as if they came "first" for it, too (Adorno, 1973 [1966]: 147).

This position, as Adorno points out, is problematic in that the identitarian class convicting the totality of which it is apart remains the thing against which it is conceived. As in the case of black Americans and the Affranchis, their "negative dialectics," their awareness of the contradictions of the heteronomous racial capitalist order did not foster a reconstitution of that order but a request that the order rid itself of a particular contradiction and allow their participation in the order, devoid of that particular contradiction, which prevented them from identifying with the Hegelian totality, i.e., that all men are created equal except the enslaved black American or the mulatto. The end result of this particular protest was in the reconfiguration of society (or the totality) in which those who exercised its reified consciousness, irrespective of skin-color, could partake in its order. In essence, the contradiction, as interpreted by the black Americans, and just the same the Affranchis, was not in the "pure" identity of the heteronomous order, which is reified as reality and existence as such, but in the praxis (as though praxis and structure are distinct) of the individuals, i.e., institutional regulators or power elites, who only allowed the participation of blacks within the order of things because they were "speaking subjects" (i.e., hybrids, who recursively organized and reproduced the agential moments of the social structure) as opposed to "silent natives" (i.e., the enslaved Africans of Bois Caïman). And herein rests the problem with attempting to reestablish an order simply based on what appears to be the contradictory practices of a reified consciousness. For in essence the totality is not "opposed by convicting it of nonidentity with itself-of the nonidentity it denies, according to its own 
concept," but on the contrary, the particular is opposed by the constitutive subjects for not exercising its total identity. In the case of liberal black bourgeois America, the totality, American racial capitalist society, was opposed through a particularity, i.e., racism, which stood against their bourgeois identification with the whole. In such a case, the whole remains superior to its particularity, and it functions as such. The same holds true for the Affranchis of Haiti, but not for Boukman, the other participants of Bois Caïman, and Dessalines who went beyond the master/slave dialectic.

In order to go beyond this "mechanical" dichotomy, i.e., whole/part, subject/object, master/slave, universal/particular, society/individual, etc., by which society or more specifically the object formation of modernity up till this point in the human archaeological record has been constituted, so that society can be reconstituted wherein "Being" (Dasein, Martin Heidegger's term) is nonsubjective and nonobjective, "organic" in the Habermasian sense, it is necessary, as Adorno points out, that the totality (which is not a "thing in itself") be opposed, not however, as he sees it, "by convicting it of nonidentity with itself" as in the case of black America and the Affranchis or mulattoes, but by identifying it as a nonidentity identity that does not have the "natural right" to dictate identity in an absurd world with no inherent meaning or purpose except those which are constructed, via their bodies, language, ideology, and ideological apparatuses, by social actors operating within a reified sacred metaphysic. This is not what happened in black America or with the Affranchis or mulattoes of Haiti, but I am suggesting that this is what took place with the participants of Bois Caïman within the eighteenth century Enlightenment discourse of the whites and Affranchis.

The liberal black American and the Affranchis by identifying with the totality, which Adorno rightly argues is a result of the "universal rule of forms," the idea that "a consciousness that feels impotent, that has lost confidence in its ability to change the institutions and their mental images, will reverse the conflict into identification with the aggressor" (Adorno, 1973 [1966], pg. 94), reconciled their double consciousness, i.e., the ambivalence that arises as a result of the conflict between subjectivity and forms (objectivity), by becoming "hybrid" Americans or mulattoes desiring to exercise the "pure" identity of the American and French totality and reject the contempt to which they were and are subject. The contradiction of slavery in the face of equality-the totality not identifying with itself-was seen as a manifestation of individual practices, since subjectively they were part of the totality, and not an absurd way of life inherent in the logic of the totality. Hence, their protest was against the practices of the totality, not the totality itself, since that would mean denouncing the consciousness that made them whole. On the contrary, Boukman, the participants at Bois Caïman, and Dessalines decentered or "convicted" the totality of French modernity not for not identifying with itself, but as an adverse "sacred-profaned" cultural possibility against their own "God-ordained" possibility (alternative object formation), Haitian/
Vilokan Idealism, which they were attempting to exercise in the world. This was the pact the participants of Bois Caïman made with their loas/lwa, Ezili Danto, when they swore to neither allow inequality on the island, nor worship the god's of the whites "who has so often caused us to weep." In fact, according to Haitian folklore, the lwa, Ezili Danto, who embodied Faitman, or Mambo Fatiman, descended from the heavens and joined the participants of Bois Caïman when they initially set-off to burn the plantations in 1791, but her tongue was subsequently removed by the other participants so that she would not reveal their secrets should she be captured by the whites. Haiti has never been able to live out this pact the participants of Bois Caïman made to Ezili Danto, given the liberal bourgeois Affranchis's, backed by their former colonizers, America and France, claims to positions of economic and political power positions, which have resulted in the passage of modern rules and laws grounded in the Protestant Ethic and the spirit of capitalism that have caused the majority of the people to weep in dire poverty as wage-laborers in an American dominated Protestant postindustrial capitalist world-system wherein the African masses are constantly being forced via ideological apparatuses such as Protestant missionary churches, industrial parks, tourism, and athletics, for examples, to adopt the liberal bourgeois Protestant ethos of the Affranchis and the black Americans against the Vodou ideology and its ideological apparatuses.

\section{References}

1. Mocombe Paul C (2017) The Protestant Ethic and the Spirit of Capitalism; and the Vodou Ethic and the Spirit of Communism. Sociology 51(1): 7690.

2. Douglas M (1986) How Institutions Think. New York, USA.

3. Du Bois, Laurent (2004) Avengers of the New World. Harvard University Press, USA.

4. Buck-Morss S (2009) Hegel, Haiti, and Universal History.University of Pittsburgh Press, Pittsburgh USA.

5. Ramsey Kate (2011) The Spirits and the Law: Vodou and Power in Haiti. Chicago: University of Chicago Press 117(4): 1176-1178.

6. Mocombe Paul C (2016) The Vodou Ethic and the Spirit of Communism: The Practical Consciousness of the African People of Haiti. University Press of America, Maryland, USA 22(2): 163-166.

7. Patterson Orlando (1982) Slavery and Social Death: A Comparative Study. Cambridge, Massachusetts: Harvard University Press, USA 6(2): 328-330.

8. Reed Adolph L (1997) WEB Du Bois and American Political Thought: Fabianism and the Color Line. New York and Oxford: Oxford University Press, USA 92(4): 936-937.

9. Mocombe Paul C (2004) Who Makes Race Matter in Post-Industrial Capitalist America? Race, Gender \& Class 11(4): 30-47.

10. Frazier, Franklin E (1957) Black Bourgeoisie: The Rise of a New Middle Class. The Free Press, New York, USA.

11. Hare N (1991) The Black Anglo-Saxons. Chicago: Third World Press, England.

12. Woodson Carter G (1969) The Mis-Education of the Negro. Associated Publishers Inc, Washington, USA 20(2): 307.

13. Kardiner A, Lionel O (1951) The Mark of Oppression: Explorations in the Personality of the American Negro. Meridian (edition), USA. 
14. Althusser L (2001) Lenin and Philosophy and Other Essays. Monthly Review Press, New York, USA.

15. Althusser Louis, Étienne Balibar (1970) Reading Capital (Ben Brewster, Trans.), London, UK.

16. Asante Molefi K (1990) Kemet, Afrocentricity and Knowledge. Africa World, New Jersey, USA.

17. Balibar Etienne, Immanuel Wallerstein (1991) Race, Nation, Class: Ambiguous Identities. London, UK.

18. Bell Daniel (1985) The Social Sciences Since the Second World War. New Brunswick, USA.

19. Billingsley Andrew (1968) Black Families in White America. New Jersey, USA.

20. Billingsley Andrew (1970) Black Families and White Social Science. Journal of Social Issues 26: 127-142.

21. Billingsley Andrew (1993) Climbing Jacob's Ladder: The Enduring Legacy of African American Families. New York, USA.

22. Blassingame John W (1972) The Slave Community: Plantation Life in the Antebellum South. New York, USA.

23. Boskin Joseph (1965) Race Relations in Seventeenth-Century America: The Problem of the Origins of Negro Slavery. In: Donald N (Ed.), The Origins of American Slavery and Racism. Charles E Merrill Publishing Co, Ohio, USA, pp: 95-105.

24. Bourdieu Pierre (1990) The Logic of Practice (Richard Nice, Trans.) Stanford University Press, California, USA

25. Bourdieu Pierre (1984) Distinction: A Social Critique of the Judgement of Taste (Richard Nice, Trans.). Cambridge MA: Harvard University Press, USA.

26. Brecher Jeremy, Tim Costello (1998) Global Village or Global Pillage: Economic Reconstruction from the bottom up (second edition). South End Press, USA

27. Chase-Dunn Christopher, Peter Grimes (1995) World-Systems Analysis. Annual Review of Sociology 21: 387-417.

28. Chase-Dunn Christopher, Richard Rubinson (1977) Toward a Structura Perspective on the World-System. Politics \& Society 7(4): 453-476.

29. Chase-Dunn Christopher (1975) The effects of international economic dependence on development and inequality: A cross-national study. American Sociological Review 40: 720-738.

30. Clarke, John Henrik, (1970) Black Titan: WEB Du Bois. Beacon Press, Boston, USA.

31. Cohen J (2002) Protestantism and Capitalism: The Mechanisms of Influence. Aldine de Gruyter, New York, USA

32. Coser Lewis A (1956) The functions of social conflict. New York, USA.

33. Crothers Charles (2003) Technical Advances in General Sociological Theory: The Potential Contribution of Post-Structurationist Sociology. Perspectives 26(3): 3-6.

34. Dahrendorf Ralf (1959) Class and Class Conflict in Industrial Society. Stanford, Stanford University Press, California, USA.

35. Douglas M (1986) How Institutions Think. New York, USA.

36. Drake St Claire (1965) The Social and Economic Status of the Negro in the United States. In: Talcott Parsons and Kenneth B Clark (Eds.), The Negro American. Houghton Mifflin Company, Boston, USA, pp. 3-46.

37. Du Bois WEB (1995) The Souls of Black Folk. Penguin Putnam Inc, New York, USA.

38. Du Bois, Laurent (2004) Avengers of the New World. Massachusetts: Harvard University Press, USA.

39. Fanon Frantz (1967) Black Skin, White Masks (Charles Lam Markmann, Trans.). New York, USA.
40. Fanon Frantz (1963) The Wretched of the Earth (Constance Farrington, Trans). New York, USA.

41. Foucault Michel (1977) Discipline and Punish: The Birth of the Prison (Alan Sheridan, Trans.). London, UK.

42. Franklin, John Hope, Alfred A Moss (2000) From Slavery to Freedom: A History of African Americans (18 ${ }^{\text {th }}$ Edition). New York, USA.

43. Fraser Nancy (1997) Justice Interruptus: Critical Reflections on the Postsocialist Condition. Routledge, London, UK

44. Frazier Franklin E (1939) The Negro Family in America. Chicago: University of Chicago Press, Illinois, USA.

45. Frazier Franklin E (1968) The Free Negro Family. New York: Arno Press and The New York Times, New York, USA

46. Gadamer Hans-Georg (2002) Truth and Method ( $2^{\text {nd }}$ edition), Joel Weinsheimer and Donald G Marshall, Trans.). New York: Continuum, New York, USA

47. Gartman David (2002) Bourdieu's Theory of Cultural Change: Explication, Application, Critique. Sociological Theory 20(2): 255-277.

48. Gates Henry Louis, Cornel West (1996) The Future of the Race. Vintage Books, New York, USA.

49. Genovese, Eugene Roll, Jordan Roll (1974) Pantheon Books, New York, USA

50. Geronimus, Arline T, Phillip Thompson F (2004) To Denigrate, Ignore, or Disrupt: Racial Inequality in Health and the Impact of a Policy-induced Breakdown of African American Communities. Du Bois Review: Social Science Research on Race 1(2): 247-279.

51. Giddens Anthony (1984) The Constitution of Society: Outline of the Theory of Structuration. Cambridge: Polity Press, England, UK.

52. Gilroy Paul (1993) The Black Atlantic: Modernity and Double Consciousness. Cambridge, Massachusetts: Harvard, England.

53. Glazer Nathan, Daniel P Moynihan (1963) Beyond the Melting Pot. Cambridge: Harvard University Press, England.

54. Gramsci Antonio (1959) The Modern Prince, and Other Writings. International Publishers, New York, USA.

55. Gutiérrez Ramón A (2004) Internal Colonialism: An American Theory of Race. Du Bois Review: Social Science Research on Race 1(2): 281-295.

56. Gutman Herbert (1976) The Black Family in Slavery and Freedom 17501925. Pantheon 4(1-2): 161-168.

57. Habermas Jürgen (1987) The Theory of Communicative Action: Lifeworld and System: A Critique of Functionalist Reason (Volume 2, Thomas McCarthy, Trans.). Beacon Press, Boston, USA.

58. Habermas Jürgen (1984) The Theory of Communicative Action: Reason and the Rationalization of Society (Volume 1, Thomas McCarthy, Trans.). Beacon Press, USA.

59. Harding Vincent (1981) There is a River: The Black Struggle for Freedom in America. Harcourt Brace \& Company, New York, USA.

60. Harris Marvin (1999) Theories of culture in postmodern times. Walnut Creek, California: AltaMira Press, California, USA

61. Harris David R, Jeremiah Joseph Sim (2002) Who is Multiracial? Assessing the Complexity of Lived Race. American Sociological Review 67(4): 614-627.

62. Hogue Lawrence W (1996) Race, Modernity, Postmodernity: A look at the History and the Literatures of People of Color Since the 1960s. Albany: State University of New York Press, New York, USA.

63. Holloway Joseph E (1990) Africanisms in American Culture. Bloomington and Indianapolis: Indiana University Press, India.

64. Holloway Joseph E (1990b) The Origins of African-American Culture. In Joseph Holloway (Edition), Africanisms in American Culture (19-33). 
Bloomington and Indianapolis: Indiana University Press 40(1): 43-59.

65. Horkheimer Max, Theodor W Adorno (1944) Dialectic of Enlightenment (John Cumming, Trans.). Continuum, New York, USA.

66. Horne Gerald (1986) Black and Red: WEB Du Bois and the Afro-American Response to the Cold War, 1944-1963. New York: State University of New York Press, New York, USA.

67. Hudson Kenneth, Andrea Coukos (2005) The Dark Side of the Protestant Ethic: A Comparative Analysis of Welfare Reform. Sociological Theory 23(1): 1-24.

68. James CLR (1986) The Black Jacobins: Toussaint L Ouverture and the San Domingo Revolution. Vintage.

69. Jameson Fredric, Masao Miyoshi (1998) The Cultures of Globalization. Durham: Duke University Press pp: 416.

70. Karenga Maulana (1993) Introduction to Black Studies. California: The University of Sankore Press, USA.

71. Kellner Douglas (2002) Theorizing Globalization. Sociological Theory 20 (3): 285- 305

72. Kurtz Lester R (2007) Gods in the Global Village: The World's Religions in Sociological Perspective. California: Sage Publications, USA.

73. Levine Lawrence W (1977) Black Culture and Black Consciousness: Afro-American Folk Thought from Slavery to Freedom. Oxford University Press, New York, USA.

74. Lincoln Eric C, Lawrence H Mamiya (1990) The Black Church in the African American Experience. Duke University Press, Durham and London, UK.

75. Lukács Georg (1971) History and Class Consciousness: Studies in Marxist Dialectics (Rodney Livingstone, Trans.). The MIT Press, USA.

76. Lukács Georg (2000) A Defence of History and Class Consciousness: Tailism and the Dialectic (Esther Leslie, Trans.). London, UK.

77. Lyman Stanford M (1997) Postmodernism and a Sociology of the Absurd and Other Essays on the "Nouvelle Vague" in American Social Science. Fayetteville: The University of Arkansas Press, USA

78. Lyman Stanford M, Arthur J Vidich (1985) American Sociology: Worldly Rejections of Religion and Their Directions. New Haven and London: Yale University Press, USA.

79. Lyman Stanford M (1972) The Black American in Sociological Thought. New York, USA

80. Massey DS, Denton NA (1993) American Apartheid: Segregation and the Making of the Underclass. Cambridge, MA: Harvard University Press, USA.

81. Marable Manning (1986) WEB Du Bois: Black Radical Democrat. Boston: Twayne Publishers, USA.

82. Marcuse Herbert (1964) One-Dimensional Man. Boston: Beacon Press, USA.

83. Marcuse Herbert (1974) Eros and Civilization: A Philosophical Inquiry into Freud. Boston: Beacon Press, USA.

84. Marshall Gordon (1998) A Dictionary of Sociology (Second edition) Oxford: Oxford University Press, USA.

85. Marx Karl, Friedrich Engels (1964) The Communist Manifesto. Penguin Books, London, England.

86. Marx Karl (1992) Capital: A Critique of Political Economy (Volume 1, Samuel Moore and Edward Aveling, Trans.). International Publishers, New York, USA

87. Marx Karl (1998) The German Ideology. Prometheus Books, New York USA.

88. Mason Patrick L (1996) Race, Culture, and the Market. Journal of Black Studies 26(6): 782-808.
89. Meier August (1963) Negro Thought in America, 1880-1915: Racial Ideologies in the Age of Booker T. Washington. Ann Arbor: The University of Michigan Press, USA.

90. Meier August, Elliott M Rudwick (1976) From Plantation to Ghetto; an Interpretive History of American Negroes. Hill and Wang, New York, USA.

91. McMichael Philip (2008) Development and Social Change: A Global Perspective. Sage Publications, USA.

92. Mocombe Paul C (2005) Education in Globalization. University Press of America, Maryland, USA.

93. Mocombe Paul C (2009) The Soul-less Souls of Black Folk: A Sociological Reconsideration of Black Consciousness as Du Boisian Double Consciousness. University Press of America Maryland, USA.

94. Mocombe Paul C (2015) Carol Tomlin, and Christine Callender (2017). The African Americanization of the Black Diaspora in Globalization or the Contemporary Capitalist World-System. University Press of America, Maryland, USA.

95. Mocombe Paul C (2017) The Protestant Ethic and the Spirit of Capitalism; and the Vodou Ethic and the Spirit of Communism. Sociology 51(1): 7690.

96. Mocombe Paul C (2016) "The anti-dialectical signification of Erzulie Danthor and Bois Caiman of the Haitian Revolution". African Identities $14(4)$.

97. Moynihan Daniel P (1965) The Negro Family. Department of Labor Office of Planning and Research, Washington DC, USA.

98. Murray Charles (1984) Losing Ground: American Social Policy 1950 1980. Basic Books, New York, USA, pp. 323.

99. Myrdal Gunnar (1944) An American Dilemma: The Negro Problem and Modern Democracy. Harper \& Row Publishers 4(3): 435-438.

100. Nash Gary B (1972) Red, White and Black: The Origins of Racism in Colonial America. In Donald Noel (Edition), The Origins of American Slavery and Racism. Ohio: Charles E. Merrill Publishing Co, USA, pp. 131-152.

101. Nobles Wade (1987) African American Families: Issues, Ideas, and Insights. Black Family Institute, Oakland, USA.

102. Ntarangwi M (2009) East African Hip Hop: Youth Culture and Globalization. Urbana and Chicago: University of Illinois Press, USA.

103. Ortner Sherry (1984) Theory in Anthropology Since the Sixties, Comparative Studies in Society and History 26(1): 126-166.

104. Phillips UB (1918) American Negro Slavery: A survey of the Supply, Employment, and Control of Negro Labor as Determined by the Plantation Regime. D Appleton and Company, New York, USA, pp.18771934.

105. Phillips UB (1963) Life and Labor in the Old South. Little Brown and company, Boston, USA pp. 1877-1934.

106. Polanyi Karl (2001) The Great Transformation: The Political and Economic Origins of Our Time. Beacon Press, Boston, USA.

107. Rampersad Arnold (1976) The Art and Imagination of WEB Du Bois. Cambridge, Massachusetts: Harvard University Press, USA.

108. Roediger David R (1999) The Wages of Whiteness: Race and the Making of the American Working Class. London and New York: Verso pp.191.

109. Rose Sonya O (1997) Class Formation and the Quintessential Worker In John R Hall (Editor), Reworking Class. Ithaca and London: Cornell University Press, USA pp. 133-166.

110. Rubin Vera (1960) Caribbean Studies: A Symposium. Seattle: University of Washington Press 18(2): 202.

111. Sennett Richard (1998) The Corrosion of Character. WW Norton \& Company, New York, USA. 
112. Sklair Leslie (1995) Sociology of the Global System. Baltimore: Frontiers of Globalization Research, USA, pp. 93-108.

113. Slemon Stephen (1995) The Scramble for Post-colonialism. In Bill Ashcroft et al (Editors), The Post-colonial Studies Reader. London and New York: Routledge, pp. 45-52.

114. Smiley Group Inc (2006) The Covenant with Black America. Third World Press, Chicago, USA.

115. Smith MG (1960) The African Heritage in the Caribbean. In Vera Rubin (Edition), Caribbean Studies: A Symposium. University of Washington Press, Seattle, USA pp. 34-46.

116. Sowell Thomas (1975) Race and Economics. David McKay, New York, USA.

117. Sowell Thomas (1981) Ethnic America. Basic Books, New York, USA.

118. Stack Carol B (1974) All Our Kin: Strategies for Survival in a Black Community. Harper \& Row Publishers, New York, USA.

119. Staples Robert (editor) (1978) The Black Family: Essays and Studies. Wadsworth Publishing Company, California, USA.

120. Stuckey Sterling (1987) Slave Culture: Nationalist Theory and the Foundations of Black America. New York and Oxford: Oxford University Press, UK

121. Sudarkasa Niara (1980) African and Afro-American Family Structure: A Comparison, The Black Scholar 11(8): 37-60.

122. Sudarkasa Niara (1981) Interpreting the African Heritage in AfroAmerican Family Organization. In Harriette P. McAdoo (Edition), Black Families. Sage Publications, California, USA.

123. Sundquist Eric J (1996) The Oxford WEB Du Bois Reader. New York and Oxford: Oxford University Press 35(3): 624.
124. Wallerstein Immanuel (1982) The Rise and Future Demise of the World Capitalist System: Concepts for Comparative Analysis. In: Hamza Alavi and Teodor Shanin (Eds.), Introduction to the Sociology of "Developing Societies". Monthly Review Press, New York, USA, pp. 29-53.

125. Ward Glenn (1997) Postmodernism. Hodder \& Stoughton Ltd, London, UK.

126. Watkins S Craig (1998) Representing: Hip-Hop Culture and the Production of Black Cinema. The University of Chicago Press, USA, pp. 330.

127. Weber Max (1958 [1904-1905]). The Protestant Ethic and the Spirit of Capitalism (Talcott Parsons, Trans.). Charles Scribner's Sons, New York, USA.

128. West Cornel (1993) Race Matters. Beacon Press, USA.

129. Wilson Kirt H (1999) Towards a Discursive Theory of Racial Identity: The Souls of Black Folk as a Response to Nineteenth-Century Biological Determinism. Western Journal of Communication 63(2): 193-215.

130. Wilson William J (1978) The Declining Significance of Race: Blacks and Changing American Institutions. Chicago and London: The University of Chicago Press, USA.

131. Wilson William J (1987) The Truly Disadvantaged. Chicago and London: University of Chicago Press, USA.

132. Winant Howard (2001) The World is a Ghetto: Race and Democracy since World War II. Basic Books, New York, USA.

133. Wright Kai (2001) The African American Archive: The History of the Black Experience in Documents. Black Dog \& Leventhal Publishers, New York, USA.
To Submit Your Article Click Here: Submit Articte

DOI: 10.32474/JAAS.2019.01.000104

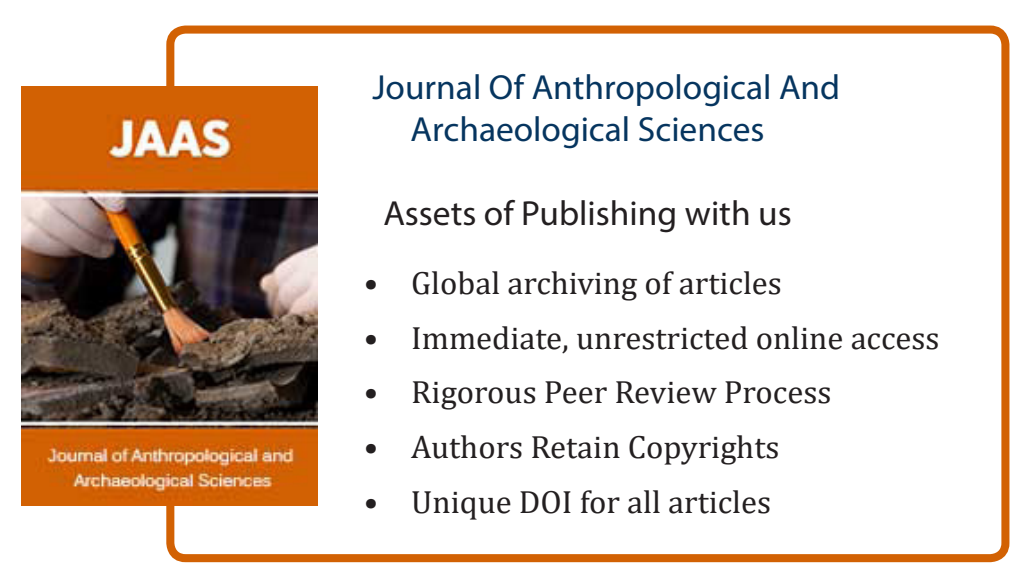

